\title{
Michael Oriard on NCAA Academic Reform: Academics Over Dollars
}

\author{
Kenneth L. Shropshire \\ University of Pennsylvania
}

\begin{abstract}
The purpose of this paper is to provide a response to Michael Oriard's keynote address. The paper highlights the link between monies generated through intercollegiate athletics and calls for academic reforms. There is also need for examination of how increased participant diversity coincided and influenced these dynamics-a connection frequently overlooked.
\end{abstract}

Professor Oriard's (2012) presentation provides us all with a reminder of the priorities in collegiate sports absent from the conversations delivered most recently by American public intellectuals: academics over dollars. He also makes clear that the most prominent recent pieces by Taylor Branch in The Atlantic (2011) and Joe Nocera in the New York Times Magazine (2011) represent the works of a modernday Christopher Columbus; they were not the first to find the issues, but they have certainly garnered them broader attention. The academic-reform and compensation issues were with us even before the Knight Commission of the past few decades or even the Carnegie Commission in 1929 (Savage, 1929).

Oriard's paper (2012) provides an impressive time line of the history of the National Collegiate Athletic Association (NCAA) and the academic-reform issue. He takes us back to the Teddy Roosevelt trope with college presidents convening to address the sports safety issue of the day-not steroids, but deaths due to the violent nature of the game. He further takes us back to historic crew events featuring compensation and "tramp" athletes. What Oriard leaves out is the proximity in time to the creation of the modern Olympiad by Baron Pierre de Coubertin. ${ }^{1} \mathrm{I}$ have always wondered if there was any connection between the two events. Were there any conversations between the originators? What is clear, intended or not, is that the Olympics and the NCAA begin in the same era, and they both evolve as huge enterprises in which labor participates without being compensated in a traditional manner. Labor participates for free because of a mythically created concept of amateurism.

Why is amateurism seemingly the fulcrum of all reform issues? How did we get into this mess? It is an understanding of that foundational amateurism background that allows us to move to the real issues Oriard (2012) is focusing us upon and away from the popular focus of the day: money. I advise those interested in the most

Shropshire is with the Wharton School, University of Pennsylvania, Philadelphia, PA. 
in-depth analysis to read David C. Young's The Ancient Myth of Greek Amateur Athletics (1985). He clearly conveys amateurism is both a word and a concept that did not even exist for the ancient Greeks. He points us squarely to Victorian England and then later to the modern Olympiad, which bumps up against the creation of organized collegiate sports in the United States. The short answer is there is no glamorous history of amateurism. There is certainly, for many, a philosophical basis for the current professional/amateur dichotomy, but looking back, we should also at least contemplate the economic foundations of amateurism: a sporting event or any activity with free labor is likely to be more profitable for the organizers than one for which the labor is paid. But I contend, and as Oriard highlights, this money issue is much less important for society than the issues related to the quality of education received by student athletes.

Oriard notes that when we think about academic reform, we are thinking primarily about basketball and football. I agree, and I also similarly think, that blended with that thought process, we must reflect on race and other diversity issues. Oriard (2012) alludes, but does not state explicitly, that college sport was predominantly conceived for able-bodied White men. What would we learn from a fully integrated historical discussion of the path of reform incorporating people of color, persons with disabilities, and women? I am not sure. But if we do not take that approach at every juncture when we review reform issues, we risk running afoul of that adage regarding repeating history. Is there a diversity trail one should follow when contemplating academic reform issues? Do we unconsciously insert any biases into our thinking due to the composition of student athletes in a given era?

Oriard (2012) does examine to an extent the racial implications in the later years. Deeper exploration should definitely take place regarding the impact of increased diversity on academic performance. I suggest this, not so much so that we can find a culprit on which to place the blame for academic decline, but rather I do so more to examine society's poor record of education in these communities and contemplate the sad state of educational inequity simply becomes incorporated into the frame of college sport, where such diversity has not always existed.

The other issue that I find curious-related to money again-is that the increased revenues in sport have come with increased diversity. There is no real reason to find that one has driven the other. But what is curious is the focus on money in public discourse over academic performance. This relates squarely to my previous point. Is there a diversity connection that we should contemplate more deeply? There have certainly been times when the academic side dominated. As Oriard (2012) highlights, discussions of initial eligibility rules were almost full focused on the academic side, with money rarely raised in the debates of past decades.

The challenge, as Oriard (2012) raises, is finding the academic reform "fix." Even amongst those who agree that there is a need to reform collegiate sports so a better academic deliverable is produced, there is no agreement on how to accomplish this end. Unfortunately, and not surprisingly, neither his paper nor my response provides us with the definitive answer. As in the past, money is a distraction. It is a sexier topic.

If granted Oriard's (2012) "system restore" on this academic performance issue, what would we do differently? The Atlantic and the New York Times Magazine are barometers of how the most important issue is not the most focused upon issue. Branch (2011) gives us the free-market solution. Nocera (2011) suggests 
a pay scale. I have mentioned before that the problem has gotten so large, one big solution is not going to be feasible. The White Man's Burden (Easterly, 2007) focused on solving global issues related to poverty; the argument of finding the multiple successful approaches that are out there and supporting those is the way to go. What are the various academic-support programs around the country that work? Can they be replicated? Can they be tweaked? That is the path we should take, one program at a time. The mind-exploding path of a singular solution, like ending world poverty, is not likely to be found and is, in fact, a distraction on where our resources should be focused. That single focused remedy distraction coupled with the amateurism distraction, doubly deters us from implementing academic reform strategies that work.

At a minimum, academic-reform issues, in terms of academic accomplishment, must be separated from issues related to increased compensation, in whatever form. The key to me in any system restore is to restore, maintain, and support the possibility of academic success by the greatest number of student athletes.

\section{Note}

1. The modern Olympics returned in 1896; the NCAA, as we know it now, is formed in 1905.

\section{References}

Branch, T. (2011, October). The shame of college sports. The Atlantic. Retrieved from http:// www.theatlantic.com/magazine/archive/2011/10/the-shame-of-college-sports/8643/

Easterly, W. (2007). The White man's burden: Why the West's efforts to aid the rest have done so much ill and so little good. New York: Penguin.

Nocera, J. (2011, December 30). Let's start paying college athletes. New York Times Magazine. Retrieved from http://www.nytimes.com/2012/01/01/magazine/lets-start-payingcollegeathletes.html?pagewanted=all

Oriard, M. (2012). NCAA academic reform: History, context, and challenges. Journal of Intercollegiate Sport, 5, 4-18.

Savage, H. J. (1929). American college athletics. New York: Carnegie Foundation for the Advancement of Teaching.

Young, D. C. (1985). The Olympic myth of Greek amateur athletics. Chicago: Ares. 1. 